\title{
ESTABLISHMENT TECHNIQUES FOR TROPICAL LEGUMES IN THE UNDERSTORY OF A EUCALYPTUS PLANTATION ${ }^{1}$
}

Maria Luiza Franceschi Nicodemo², Francisco Humberto Dubbern de Souza ${ }^{2}$, Jose Ricardo Macedo Pezzopane ${ }^{2}$, João Carlos Teixeira Mendes ${ }^{3}$ e Waldomiro Barioni Júnior ${ }^{2}$

\begin{abstract}
This study evaluated establishment methods for a mixture of herbaceous forage legumes [Centrosema acutifolium, Clitoria ternatea, Pueraria phaseoloides, Stylosanthes Campo Grande (Stylosanthes capitata + S. macrocephala), Calopogonium mucunoides, Lablab purpureus, Arachis pintoi, and Aeschynomene villosa] under the shade of an Eucalyptus grandis plantation submitted to thinning (40\%) 8 years after planting in Anhembi, São Paulo (22 $40^{\prime} \mathrm{S}, 48^{\circ} 10^{\prime} \mathrm{W}$, altitude of $455 \mathrm{~m}$ ). The experiment started in December 2008 and consisted of the comparison of the following four types of seed incorporation by light disc harrowing: (1) broadcast sowing without seed incorporation; disc harrowing before (2) or after (3) planting, and (4) disc harrowing before and after planting. Ninety days after planting, the number of legume plants $/ \mathrm{m}^{2}$ and the percentage of ground cover by the plants varied between the treatments tested; however, the treatments had no effect on the dry matter accumulation of forage legumes. Disc harrowing before planting yielded superior results compared to the treatments without disc harrowing and disc harrowing after planting. At the end of the experimental period, the plots contained Arachis, Centrosema, Stylosanthes, and Pueraria. The dry matter accumulated by Centrosema corresponded to $73 \%$ of total dry matter yield of the plots. The participation of Arachis, Centrosema and Stylosanthes in final dry matter composition of the plots varied according to establishment method. The advantages of the use of species mixtures rather than monocultures in the understory of forest plantations were discussed.
\end{abstract}

Keywords: Pasture establishment; Agroforestry systems; Silvopastoral systems.

\section{TÉCNICAS DE IMPLANTAÇÃO DE LEGUMINOSAS TROPICAIS EM SUB- BOSQUE DE EUCALIPTO}

\begin{abstract}
RESUMO - Foram avaliados métodos de estabelecimento de um coquetel de leguminosas forrageiras herbáceas (Centrosema acutifolium, Clitoria ternatea, Pueraria phaseoloides, Estilosantes Campo Grande (Stylosanthes capitata + S. macrocephala), Calopogonium mucunoides, Lablab purpureus, Arachis pintoi e Aeschynomene vilosae) sob a sombra promovida por um bosque de Eucalyptus grandis submetido a corte de raleamento (40\%) oito anos após haver sido plantado em Anhembi, SP (2240’S, 48 $10^{\circ} \mathrm{W}, 455 \mathrm{~m}$ de altitude). O experimento foi implantado em dezembro de 2008, sendo comparadas quatro formas de enterrio das sementes por meio de gradagem leve, quais sejam: semeadura superficial a lanço não seguida de incorporação (1), gradagem antes (2) ou depois (3) da semeadura e gradagem antes e depois da semeadura (4). Noventa dias após a semeadura, o número de plantas de leguminosa $/ \mathrm{m}^{2}$ e a porcentagem de cobertura do solo pelas plantas variaram entre os tratamentos testados, os quais, entretanto, não tiveram efeito sobre o acúmulo de matéria seca das plantas de leguminosas. A gradagem antes do plantio proporcionou resultados superiores aos tratamentos sem gradagem e com gradagem após o plantio. Ao final do período experimental, as parcelas eram compostas por arachis, centrosema, estilosantes e pueraria. A matéria seca oriunda da centrosema correspondeu a 73\% do total das parcelas. A participação de arachis, centrosema e de estilosantes na composição final da matéria seca das parcelas variou com o método de implantação. Foram também discutidas as vantagens do uso de coquetel de espécies em relação ao plantio puro no sub-bosque de plantação florestal.
\end{abstract}

Palavras-chave: Estabelecimento de pastagens; Sistemas agroflorestais; Sistemas silvipastoris.

\footnotetext{
${ }^{1}$ Recebido em 13.12.2013 aceito para publicação em 15.12.2014.

${ }^{2}$ Embrapa Pecuária Sudeste, São Carlos, SP, Brazil. E-mail: <marialuiza.nicodemo@embrapa.br>, <francisco.dubbernsouza@embrapa.br>,<jose.pezzopane@embrapa.br>e<waldomiro.barioni@embrapa.br>.

${ }^{3}$ Universidade de São Paulo, 'Luiz de Queiróz', Departamento de Ciências Florestais, Piracicaba, SP, Brazil. E-mail: <jctmende@usp.br>.
} 


\section{INTRODUCTION}

The planted forest area in the world is estimated at 264 million hectares and has grown at a rate of 5 million ha/year from 2000 to 2010 (FAO, 2010). The main objectives of raising animals in the understory of planted forests are to control weeds, to reduce the risk of fires, and to generate income. This approach increases the efficiency of land use and meets one of the requirements for sustainable production of animal protein (SMIL, 2002). In tropical regions, grasses frequently predominate in the understory of forest plantations. However, they permit low animal stocking rates since the low light availability in the understory compromises the production of aboveground biomass, reduces root formation and consequently increases the susceptibility to stress, and reduces the tillering rate in grasses (GUENNI et al., 2008). In this respect, the use of legume species to occupy this stratum has been little explored, despite the potential use of these plants as producers of forage of high nutritional value and for nitrogen fixation from soil. Even considering the low productivity potential, the large amount of available area increases the interest in techniques that could improve the availability of high-quality forages under these conditions.

The conditions determining the success of forage establishment in an understory are still poorly understood. Factors that should be considered for pasture establishment and flora enrichment in an understory include the selection of adapted species, the spatial distribution of species in the area, and the techniques used for species incorporation. The presence of leaf litter, light conditions and soil temperature that differ from those of conventional tillage under full sunlight are some of the variables that potentially interfere with the germination and development of introduced species.

Specifically in the case of Eucalyptus grandis, the presence of allelochemicals in the leaf litter has been associated with reduced development and nodulation of some legumes, including Calopogonium mucunoides and Stylosanthes guianensis (POEIRAS; CARMO, 2007); however, the possibility of attenuating this problem through soil preparation was not evaluated. Leaf-litter decomposition in soil is known to release allelochemicals that can interfere with the germination and emergence of susceptible plants, affecting seed viability and seedling emergence. Residues incorporated in soil can be more toxic than those that persist on the soil surface (MORAES et al., 2011).

The objective of the present study was to evaluate the performance of a mixture of forage legumes established in the understory of a eucalyptus (Eucalyptus grandis) plantation using different planting methods.

\section{MATERIALAND METHODS}

The experiment was conducted at the Forest Science Experimental Station (Estação Experimental de Ciências Florestais) of ESALQ-USP in Anhembi, São Paulo (latitud $22^{\circ} 42^{\prime} 57,38^{\prime \prime} \mathrm{S}$, longitud $48^{\circ} 11^{\prime} 05,32^{\prime} \mathrm{W}, 455 \mathrm{~m}$ above sea level. The predominant climate of the region is Cwa (KÖPPEN, 1948), with an average annual rainfall of 1,100 mm, an annual rainfall deficiency of $25 \mathrm{~mm}$, and an average annual temperature of $20.9^{\circ} \mathrm{C}$. The soil is a dystrophic Red-Yellow Latosol of low fertility consisting of $18 \%$ clay, $9 \%$ silt, and $73 \%$ sand. The shaded area was occupied by Eucalyptus grandis planted at an initial spacing of $3 \times 2 \mathrm{~m}$ and submitted to $40 \%$ thinning at 7 years, which resulted in 1,000 plants/ha.

Analysis of soil samples $(0-20 \mathrm{~cm})$ revealed the following composition: $\mathrm{P}, 9 \mathrm{mg} / \mathrm{dm}^{3}$ (resin); organic matter, $20 \mathrm{~g} / \mathrm{dm}^{3} ; \mathrm{pH} \mathrm{CaCl}_{2}$, 3.7; exchangeable cations $\left(\mathrm{mmolc} / \mathrm{dm}^{3}\right): \mathrm{K}^{+}, 1.2 ; \mathrm{Ca}^{2+}, 2 ; \mathrm{Mg}^{2+}, 1 ; \mathrm{H}^{+}+\mathrm{Al}^{3+}, 64$; $\mathrm{Al}^{3+}, 62$; sum of bases, 4 ; cation exchange capacity, 68 ; base saturation ( $\mathrm{V} \%$ ), 6; $\mathrm{Al}^{3+}$ saturation, 94; sulfur

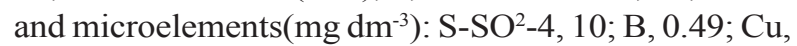
$1.0 ; \mathrm{Fe}, 88 ; \mathrm{Mn}, 8.8$, and $\mathrm{Zn}, 0.5$. In October 2008, 3 tons of lime/ha were broadcast. In addition, $80 \mathrm{~g}$ $\mathrm{KCl}, 400 \mathrm{~g}$ simple superphosphate and $40 \mathrm{~g}$ FTE BR 15 were applied to the plantation rows. On the basis of soil analysis performed in August 2009, $2.4 \mathrm{~g}$ boric acid, $40.2 \mathrm{~g} \mathrm{KCl}, 119.6 \mathrm{~g}$ simple superphosphate and 3,200 g dolomitic limestone (PRNT 90\%) were applied per plot.

A mixture of nine herbaceous legume species [Aeschynomene villosa cv. Vilomix, Alysicarpus vaginalis 'comum', Arachis pintoi cv. Mandovi, Calopogonium mucunoides 'comum', Centrosema acutifolium, Clitoria ternatea 'comum', Lablab purpureum cv. Rongai, Campo Grande stylo (Stylosanthes capitata + S. macrocephala, 80:20), and Pueraria phaseoloides 'comum') were planted after inoculation with specific Rhizobium spp strains. The seeds were sowed on December 3, 2008. The seed density was estimated based on germination tests to permit a minimum of 20 seedlings $/ \mathrm{m}^{2}$ per species.

Revista Árvore, Viçosa-MG, v.39, n.2, p.345-352, 2015 
Each plot measured $2.5 \times 5 \mathrm{~m}$. The seeds were broadcast over the plot. The leaf litter dry matter present on the surface of the experimental area was estimated to be $1,750 \mathrm{~g} / \mathrm{m}^{2}$ at the beginning of the experiment.

The following four methods of legume establishment were tested: (1) liming + broadcast sowing + broadcast fertilizer application (no disc harrowing); (2) liming + two disc harrowings + broadcast sowing + broadcast fertilizer application; (3) liming + broadcast sowing +broadcast fertilizer application+ one disc harrowing, and (4) liming + two disc harrowings + broadcast sowing + broadcast fertilizer application+ one disc harrowing. A randomized block design consisting of four treatments and five repetitions was used.

The experimental period was divided into four phases (Figure 1): establishment (December to March, 89 days); dry season 2009 (March to October 2009, 226 days); rainy season (November 2009 to May 2010, 182 days), and dry season 2010 (June to October 2010, 150 days).

The plants were evaluated regarding dry matter production and ground cover. The production of dry matter was estimated based on two $1-\mathrm{m}^{2}$ samples per plot, which were cut $10 \mathrm{~cm}$ from the ground. The samples were collected at the end of each evaluation period, followed by standardization cuts of the remaining plot. The percentage of ground cover was rated by three independent observers on a subjective visual scale ( $0 \%$ - no cover; $100 \%$ - completely covered ground) at the end of establishment and of the dry seasons. In addition, the number of seedlings was determined at the end of the establishment phase using a 0.25 $\mathrm{x} 0.25$ grid, in three repetitions/plot. Two plant samples $\left(1 \mathrm{~m}^{2}\right)$ collected at the end of the study period in October 2010 were submitted to botanical separation of their components; the separated fractions were dried for $72 \mathrm{~h}$ in a forced air circulation drying oven at $60^{\circ} \mathrm{C}$ and weighed.

Photosynthetically active radiation (PAR) was evaluated monthly between 11 and 12 am under sunlight and in the shaded plots with a ceptometer (AccuPAR LP-80, Decagon). Eight sites were chosen randomly in the N, S, E and $\mathrm{W}$ directions. The incidence of PAR in the shaded plots corresponded on average to $18 \%$ of total solar radiation $\left(231 \mu \mathrm{mol} / \mathrm{m}^{-2} / \mathrm{s}^{-1} \mathrm{vs}\right.$. $\left.1,279 \mu \mathrm{mol} \mathrm{m}^{-2} \mathrm{~s}^{-1}\right)$.
The climatic water balance (THORNTHWAITE; MATHER, 1955) was calculated from the meteorological data collected at the Estação Experimental de Ciências Florestais de Anhembi, ESALQ- USP (Figure 1).

\section{Statistical analysis}

All statistical analyses were conducted with the R statistical environment ( $R$ Development Core Team, 2008). The number of seedlings $/ 0.25 \mathrm{~m}^{2}$, ground cover and botanical composition data did not fit parametric test assumptions. Therefore, differences were analyzed with Kruskal-Wallis tests. The level of significance was set at 0.05. A multiple comparison test after KruskalWallis was also performed to assess differences between means using the pgirmess package and the Kruskalmc function (Giraudoux, 2006). The level of significance for this procedure is pointed at the corresponding table.

Dry matter accumulation was analyzed with ANOVA. Tukey test was adopted for multiple comparisons of means. The level of significance was set at 0.05.KruskalWallis and multiple comparison test after Kruskal-Wallis were performed for dry matter accumulation across dates for each treatment.

\section{RESULTS}

Ninety days after planting (March 2009), the number of seedlings per $\mathrm{m}^{2}$ and the percentage of ground cover by the plants (Table 1) were found to be influenced by the method of seed incorporation into the soil $(\mathrm{P}<0.05)$. The number of seedlings per treatment at 90 days after planting was: (1) broadcast sowing: $9.40 \pm 3.54 \mathrm{~B}$; (2) disc harrowing before planting: $19.27 \pm 8.51 \mathrm{~A}$; (3) disc harrowing after planting: $22.67 \pm 6.72 \mathrm{~A}$; (4) disc harrowing before and after planting: $28.53 \pm 12.98 \mathrm{~A}$. Means and standard deviation values followed by different letters indicate a significant difference $(\mathrm{P}<0.05)$ by multiple comparison test after Kruskal-Wallis. In the case of Brachiaria, a number of 15 to 20 plants $/ \mathrm{m}^{2}$ is desirable for good pasture formation (DIAS-FILHO, 2012); this requisite was met by all treatments, except for exclusive broadcast seeding. However, the treatments exerted no effect on dry matter accumulation at the beginning of establishment (Table 2).

Revista Árvore, Viçosa-MG, v.39, n.2, p.345-352, 2015 
In general, the treatments consisting of disc harrowing before planting provided superior results. For these treatments, disc harrowing after planting only resulted in greater ground cover at the beginning of the experiment and did not differ from the treatment consisting of disc harrowing only before planting in terms of ground cover or dry matter accumulation in the following assessments.
The dry season of 2010 was more intense than that of 2009 (Figure 1). Ground cover was expressively lower in the 2010 dry season compared to 2009 for the broadcast seeding method $(66.33 \%$ in October 2009 vs. 38.2\% in October 2010) (Table 1), but was stable for the other establishment methods. With respect to dry matter production, although a reduction was observed for all establishment methods in the 2010

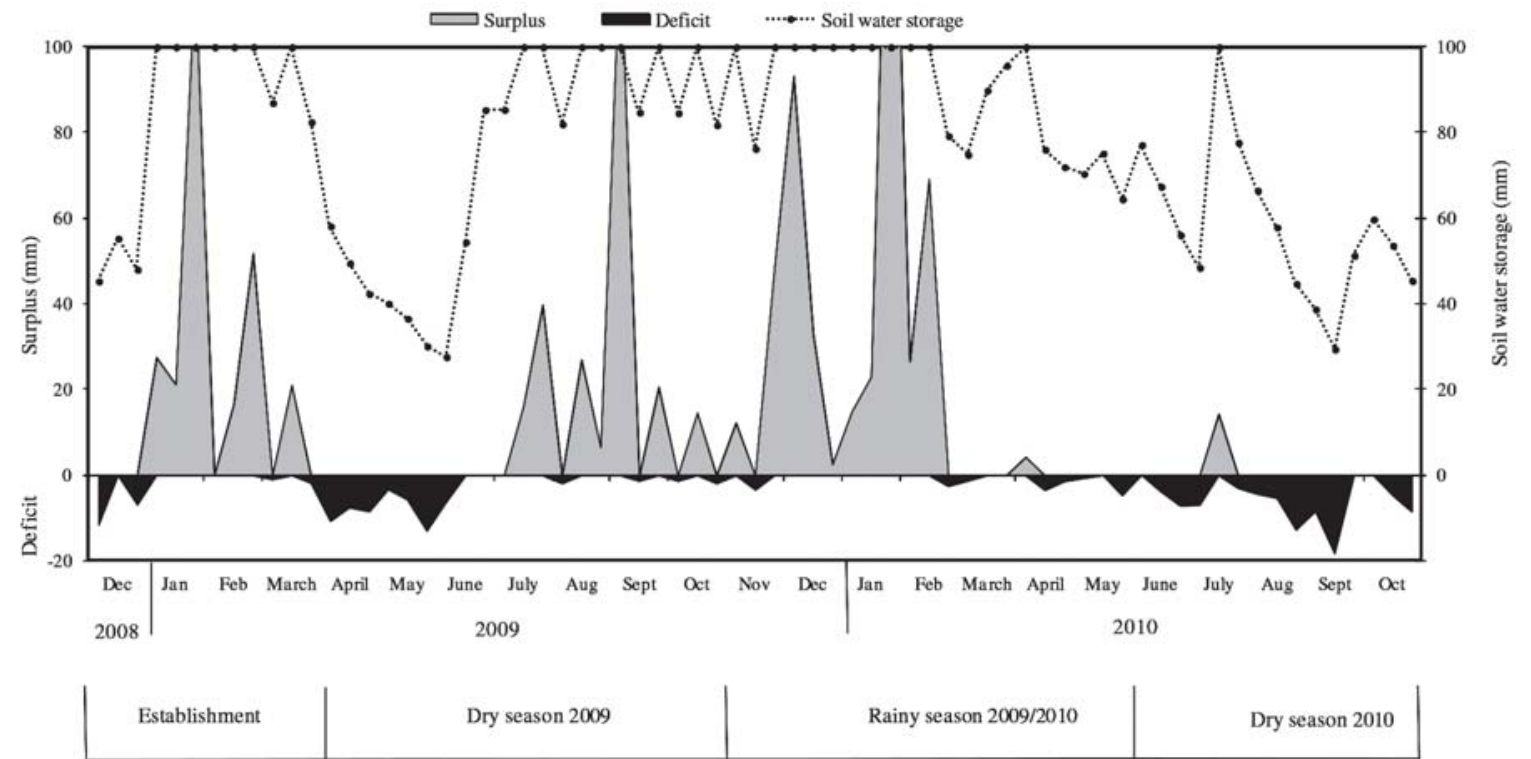

Figure 1 - Climatic water balance over the period from December 2008 to October 2010 in the Municipality of Anhembi (SP).

Figura 1 - Extrato do balanço hídrico climatológico durante o período de dezembro de 2008 a outubro de 2010, no Município de Anhembi (SP).

Table 1 - Ground cover (mean and standard deviation, \%) provided by herbaceous forage legumes grown in an Eucalyptus grandis forest at the end of four experimental phases according to different establishment methods. Anhembi (SP), 2008-2010.

Tabela 1 - Cobertura do solo (média e desvio-padrão, em \%) proporcionada por plantas de espécies leguminosas herbáceas cultivadas sob bosque de Eucalyptus grandis ao final de quatro etapas experimentais, em razão de diferentes métodos de implantação. Anhembi (SP), 2008-2010.

\begin{tabular}{llllcl}
\hline \multirow{2}{*}{ Date } & \multicolumn{5}{c}{ Treatment } \\
\cline { 2 - 5 } & Broadcast sowing & $\begin{array}{l}\text { Disc harrowing } \\
\text { before planting }\end{array}$ & $\begin{array}{c}\text { Disc harrowing } \\
\text { after planting }\end{array}$ & $\begin{array}{c}\text { Disc harrowing before } \\
\text { and after planting }\end{array}$ & Mean \\
\hline March 2009 & $53.67 \pm 8.34 \mathrm{cBC}$ & $76.00 \pm 9.10 \mathrm{bB}$ & $78.67 \pm 6.67 \mathrm{abA}$ & $86.33 \pm 5.16 \mathrm{aA}$ & $73.67 \pm 14.26$ \\
October 2009 & $66.33 \pm 10.77 \mathrm{abAB}$ & $68.67 \pm 15.41 \mathrm{aB}$ & $49.00 \pm 19.66 \mathrm{bB}$ & $66.67 \pm 9.19 \mathrm{abB}$ & $62.67 \pm 16.12$ \\
May 2010 & $85.20 \pm 14.70 \mathrm{abA}$ & $92.73 \pm 3.84 \mathrm{aA}$ & $76.67 \pm 15.55 \mathrm{bA}$ & $88.33 \pm 5.92 \mathrm{abA}$ & $85.73 \pm 1.61$ \\
October 2010 & $38.20 \pm 13.83 \mathrm{bC}$ & $70.13 \pm 10.32 \mathrm{aB}$ & $46.93 \pm 17.07 \mathrm{bB}$ & $69.87 \pm 8.88 \mathrm{aB}$ & $56.28 \pm 18.96$ \\
Mean & $60.85 \pm 21.04$ & $76.88 \pm 14.06$ & $62.82 \pm 21.31$ & $77.80 \pm 12.15$ & $69.59 \pm 19.17$ \\
\hline
\end{tabular}

Means in the same row followed by the same lowercase letter do not differ from one another (Kruskal - Wallis multiple comparisons tests, $\mathrm{P}<0.05$ ). Means in the same column followed by the same capital letter do not differ from one another (Kruskal - Wallis multiple comparisons tests, $\mathrm{P}<0.05)$.

Revista Árvore, Viçosa-MG, v.39, n.2, p.345-352, 2015 
Table 2 - Dry matter accumulation (mean \pm standard error, $\mathrm{kg} / \mathrm{ha}$ ) provided by herbaceous forage legumes grown in an Eucalyptus grandis forest at the end of four experimental phases according to different establishment methods. Anhembi (SP), 2008-2010.

Tabela 2 - Montante de matéria seca (média \pm erro-padrão, $\mathrm{kg} / \mathrm{ha}$ ) acumulada por plantas de leguminosas herbáceas cultivadas sob sombra de bosque de Eucalyptus grandis ao final de quatro etapas experimentais, em razão de diferentes métodos de implantação. Anhembi (SP), 2008-2010.

\begin{tabular}{lcllcl}
\hline \multirow{2}{*}{ Date } & \multicolumn{5}{c}{ Treatment } \\
\cline { 2 - 5 } & Broadcast sowing & $\begin{array}{c}\text { Disc harrowing } \\
\text { before planting }\end{array}$ & $\begin{array}{c}\text { Disc harrowing } \\
\text { after planting }\end{array}$ & $\begin{array}{c}\text { Disc harrowing before } \\
\text { and after planting }\end{array}$ & Mean \\
\hline March 2009 & $528.1 \pm 240.4 \mathrm{aA}$ & $639.4 \pm 203.9 \mathrm{aA}$ & $501.8 \pm 129.5 \mathrm{aA}$ & $672.5 \pm 243.8 \mathrm{aA}$ & $585.4 \pm 214.1$ \\
October 2009 & $317.0 \pm 104.0 \mathrm{aA}$ & $302.2 \pm 69.8 \mathrm{abAB}$ & $190.6 \pm 79.9 \mathrm{cA}$ & $255.9 \pm 99.8 \mathrm{bcA}$ & $266.4 \pm 99.4$ \\
May 2010 & $603.6 \pm 183.6 \mathrm{aAB}$ & $751.6 \pm 201.0 \mathrm{aBC}$ & $565.2 \pm 189.2 \mathrm{aB}$ & $645.6 \pm 158.3 \mathrm{aB}$ & $641.5 \pm 190.1$ \\
October 2010 & $68.9 \pm 42.1 \mathrm{bB}$ & $144.4 \pm 60.7 \mathrm{aC}$ & $82.6 \pm 78.3 \mathrm{abB}$ & $146.6 \pm 56.2 \mathrm{aB}$ & $110.6 \pm 68.4$ \\
Mean & $379.4 \pm 261.4$ & $459.4 \pm 287.9$ & $335.0 \pm 239.6$ & $430.14 \pm 279.1$ & $401.0 \pm 269.4$ \\
\hline
\end{tabular}

Means in the same row followed by the same lowercase letter do not differ from one another (Tukey test, $\mathrm{P}<0.05$ ). Means in the same column followed by the same capital letter do not differ from one another (Kruskal - Wallis multiple comparisons tests, $\mathrm{P}<0.05$ ).

dry season compared to 2009 , the greatest decline in production was also seen for the broadcast seeding method $(21.7 \%$ of production of the previous dry season vs. $43.3 \%$ to $57.3 \%$ of the previous dry season for the others).

Only plants of the species Arachis pintoi, Centrosema acutifolium, Campo Grande stylo, and Pueraria phaseoloides persisted at the end of the experimental period (Table 3). The dry matter accumulated by C. acutifolium corresponded on average to $73 \%$ of total dry matter yield of the plots; however, the fraction of total dry matter produced per plot, represented by A. pintoi, C. acutifolium and Campo Grande stylo plants, varied according to establishment method $(\mathrm{P}<0.05)$.

\section{DISCUSSION}

The objective of the present study was to test the hypothesis that the success of herbaceous forage legume establishment depends on the planting method used. The main assumption was that methods permitting the best seed-soil contact, to cover the seed with an adequate layer of soil, and to protect from seed predation would maximize the emergence of seedlings. In the present experiment using a mixture of seeds of nine cultivars, it was possible to identify the method that provided the highest dry matter accumulation by herbaceous legumes, which was mainly due to the fact that the method favored seedling emergence. It was not possible to determine with certainty potential association between legume species and establishment method. In order to determine such association it would be necessary to test different seed lots of each species/cultivar, which differ in terms of physiological quality.

The results regarding ground cover and dry matter accumulation obtained with the broadcast seeding method (Tables 1 and 2), although lower than those observed for the other treatments, were unexpected since less favorable conditions for seed establishment on the soil surface than those seen when seeds are incorporated

Table 3 - Botanical composition (\% of total dry matter) at the end of the experimental period (October 2010). Tabela 3 - Composição botânica (\% do total de matéria seca) no final do período experimental (outubro/2010).

\begin{tabular}{lcccc}
\hline Treatment & Arachis & Centrosema & Stylosanthes & Pueraria \\
\hline Broadcast sowing & $8.55 \mathrm{~b}$ & $63.91 \mathrm{~b}$ & $2.90 \mathrm{~b}$ & 24.64 \\
Disc harrowing before planting & $3.18 \mathrm{~b}$ & $77.23 \mathrm{a}$ & $13.98 \mathrm{a}$ & 5.61 \\
Disc harrowing after planting & $16.94 \mathrm{a}$ & $72.00 \mathrm{ab}$ & $2.68 \mathrm{ab}$ & 8.37 \\
Discharrowing before and after planting & $9.30 \mathrm{ab}$ & $80.00 \mathrm{a}$ & $5.05 \mathrm{ab}$ & 5.59 \\
Mean & 9.49 & 73.30 & 6.15 & 11.05 \\
P-value & 0.20 & 0.05 & 0.10 & - \\
\hline
\end{tabular}

Means in the same column followed by the same lowercase letter do not differ from one another (Kruskal - Wallis multiple comparisons tests). 
by disc harrowing were expected, especially in terms of the availability of sufficient amounts of water to permit germination (McWILLIAMS; DOWLING 1970). The shade provided by the trees and the accumulated layer of leaf litter (estimated at $1,750 \mathrm{~g} / \mathrm{m}^{2}$ ) on the soil surface may have contributed to protect the seeds from drying. When planted in full sunlight, radiation levels are invariably sufficient to induce the germination of seeds of positively photoblastic species. According to Forcella et al (2000), $1,000 \mu \mathrm{mol} / \mathrm{m}^{-2}$ is sufficient to stimulate germination of these seeds. On the soil surface, the greater light availability and alternating temperatures can stimulate germination of a variety of species (CARMONA; VILLA BÔAS, 2001). However, the amount of radiation available in understories may eventually be insufficient.

Furthermore, while the leaf litter can contribute to the absorption and maintenance of necessary seed moisture content, it may also represent a physical barrier between the seed and soil, where water availability is more stable. The failure of the root to penetrate the soil during germination can limit seed establishment (McWILLIAMS; DOWLING, 1970). In addition, the leaf litter of eucalyptus includes rhytidomes of the trees, posing a mechanical barrier that compromises the establishment of new plants (SILVA et al., 2010). In broadcast seeding, the greater difficulty in obtaining adequate conditions for seed germination and initial development was demonstrated by the smaller number of seedlings per area $(\mathrm{P}<0.05)$, whereas disc harrowing before planting increased the mean number of seedlings per area. This effect might be explained by the partial burial of seeds, providing better conditions for germination and establishment, in addition to reducing seed predation. The percentage of ground cover was lower for broadcast seeding, although the soil preparation method exerted no effect on dry matter production during the early stage of seedling development $(\mathrm{P}>0.05)$.

An increase in the number of seedlings per area is not always reflected in an increased dry matter production. Lovadini (1971) compared methods of planting perennial soybean (Neonotonia wightii) and observed that, although planting in shallow furrows favored the number of seedlings per square meter, higher green mass production was observed for broadcast seeding followed by light soil compaction, possibly because of the lower competition between plants. Similarly, Leite et al. (1980), evaluating planting methods of Siratro (Macroptilium atropurpureum), observed positive effects of an increase in seeding density on the number of plants per area, but this fact did not result in an increase in ground cover percentage or dry matter production.

Only four species of the mixture persisted at the end of the experimental period (Table 3): Arachis pintoi, Centrosema acutifolium, Calopogonium mucunoides and Campo Grande stylo. The dry matter accumulated by Centrosema corresponded on average to $73 \%$ of total dry matter yield of the plots. Centrosema acutifolium is considered to be a drought-but not a shade tolerant species (COOK et al., 2005), this plant has been used in understories of forest plantations and coconut plantations where the amount of light reaching the soil surface is about $60 \%$ (FAO, 2009), a more favorable situation than that of the present study.

The treatment consisting of disc harrowing before and after planting consistently provided good results ( $\mathrm{P}<0.05$; Tables 1,2 and 3 ) in terms of biomass production and ground cover, favoring plant development, except for dry matter production during the first dry season. The treatment consisting of disc harrowing before planting provided identical results, except for a lower ground cover during the establishment phase. Considering that disc harrowing before and after planting is more expensive and its advantages are limited, exclusive pre-planting disc harrowing may be indicated for legume establishment in understories.

Factors such as soil moisture content, planting depth and interference from the leaf litter (chemical composition, physical barrier) can affect the germination and survival of seedlings and are influenced by the planting technique. Broadcast seeding was less indicated for Centrosema (approximately 18,000 seeds/kg) and Stylosanthes $(500,000$ seeds $/ \mathrm{kg})$ than planting techniques consisting of pre-planting disc harrowing ( $\mathrm{P}<0.05$; Table 3), with no significant difference for Pueraria (88,000 seeds/kg). Arachis (6,500 seeds $/ \mathrm{kg}$ ) showed a better response with disc harrowing after planting. The vertical distribution of seeds along the soil profile shows a close correlation with the type of soil preparation, affecting the environmental conditions to which the seeds are subjected (CARMONA;

Revista Árvore, Viçosa-MG, v.39, n.2, p.345-352, 2015

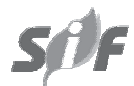


VILLA BÔAS, 2001). This fact may explain the lower performance of Stylosanthes using post-planting disc harrowing, which may have promoted deeper burial of the seeds. Broadcast seeding of small seeds is recommended since the seedlings need to reach the soil surface after germination. The seedling obtains the energy necessary for this process exclusively from the reserves stored in the seed; if the energy is not sufficient, the seedling may die (FORCELLA et al., 2000). Deep burial accelerates the deterioration of seeds, including the loss of viability, especially in situations of high temperature and humidity (CARMONA; VILLA BÔAS, 2001). Arachis, a large seed species, on the other hand, benefited from deeper planting.

One issue to be considered for the formation or enrichment of pasture areas in understories of forest plantations is the combination of species to be used. The use of a mixture of various pasture species better meets the nutritional requirements of animals by supplying more complex diets and minimizing risks. It is possible to plant monospecific swards of adapted legumes or to use a mixture of species with complementary characteristics. Species with desirable characteristics that are able to grow in shade may present distinct rhythms of development under the same conditions, such as high biomass production in the first year postseeding (Lablab purpureum) or slow initial development (Arachis pintoi). This fact implies periods of insufficient ground cover, increasing the risk of erosion and reducing nutrient availability for animals. When a mixture of species is planted, ground cover will be always satisfactory even if one species predominates and inhibits the development of others at certain times.

Plots exclusively containing Arachis pintoi grown in shade showed only $33 \%$ of ground cover at the end of the establishment period (data submitted for publication in another article), contrasting with the $73.7 \%$ average cover observed for the species mixture (Table 1). On the other hand, Lablab exhibited excellent performance on pure sown plots, with $97 \%$ ground cover at 90 days post-planting. However, this species had disappeared from both pure and mixed plots at the end of the experimental period (October 2010). The combination of species permits those that encounter more favorable conditions to occupy the available niche and to meet the needs of the producer in terms of soil protection or forage production.
Interestingly enough, inspection of the experimental area 36 months (October 2013) after the end of this work, during which the area was kept ungrazed, found the understory completely dominated by plants of Pueraria phaseoloides, although a few plants of Arachis and Centrosema also were found. Alterations in the amount of light incident through the tree canopy and in the frequency of cuts applied during the previously concluded experimental period may have contributed to this situation.

\section{CONCLUSIONS}

Under the conditions of litter-covered understory of Eucaliptus forest, pre-planting disc harrowing of a mixture of broadcasted seeds of different herbaceous, tropical, forage legume species provided better ground cover and higher dry matter production than treatments without disc harrowing or with post-planting disc harrowing. Centrosema acutifolium accounted for $73 \%$ of total dry matter yield of the mixed plots at the end of the experimental period and continued to predominate for an additional 23 months, showing adaptation of the plant to the local conditions of seasonal drought and intense shade of a Eucalyptus grandis forest. Furthermore, Lablab, although not persisting throughout the study period, provided rapid and broad soil surface coverage, demonstrating its value as a member of the seed mixture of legumes destined for planting in these situations.

\section{ACKNOWLEDGEMENTS}

We thank FAPESP for financial support, Embrapa Agrobiologia for the inocula used for seed pelleting, and Sementes Piraí (Piracicaba, SP), Sementes Safrasul (Campo Grande, MS), Prof. Dr. José Leonardo de Moraes Gonçalves and the employees of Estação Experimental de Ciências Florestais de Anhembi (ESALQ-USP) for operational support.

\section{REFERENCES}

CARMONA, R.; VILLAS BOAS, H.D.C. Dinâmica de sementes de Bidens pilosa no solo.

Pesquisa Agropecuária Brasileira, v.36, n.3, 2001. Available at: $<$ http://www.scielo.br/ scielo.php?pid=S0100-

204X2001000300009\&script $=$ sci_arttext $>$. Accessed Sept. 13, 2013.

Revista Árvore, Viçosa-MG, v.39, n.2, p.345-352, 2015 
COOK, B.G.; PENGELLY, B.C.; BROWN, S.D.; DONNELLY, J.L.; EAGLES, D.A.; FRANCO, M.A.; HANSON, J.; MULLEN, B.F., PARTRIDGE, I.J.; PETERS, M.; SCHULTZE-KRAFT, R. Tropical Forages: an interactive selection tool. 2005. Available at: $<$ http://

www.tropicalforages.info>. Accessed Feb. 28, 2012

DIAS-FILHO, M.B. Formação e manejo de pastagens. Belém: Embrapa Amazônia Oriental, 2012.9p. (Embrapa Amazônia Oriental.

Comunicado Técnico, 235).

\section{FOOD AND AGRICULTURE ORGANIZATION OF} THE UNITED NATIONS - FAO. Available at: $<$ http://www.fao.org/docrep/013/i1757e/ i1757e.pdf $>$. Accessed Sept. 5, 2012.

FORCELLA, F.; ARNOLD, R. L. B.; SANCHEZ, R.; GHERSA, C. M. Modeling seedling emergence. Field Crops Research, v.67, n.2, p.123-139, 2000.

GIRAUDOUX, P. pgirmess: data analysis in ecology. 2006. R package version 1.3.1. Available at: <http://cran.r-project.org/web/packages/ pgirmess/index.html>. Acessed Dec. 11, 2013.

GUENNI, O.; SEITER, S.; FIGUEROA, R. Growth responses of three Brachiaria species to light intensity and nitrogen supply. Tropical Grasslands, v.42, n.1, p.75-87, 2008.

KÖPPEN, W. Climatologia, Buenos Aires: Fondo de Cultura Económica, 1948. 479 p.

LEITE, V.B.O.; ABRAMIDES, P.L.G.; BIANCHINE, D. Comparação de quatro sistemas de semeadura mecanizada no estabelecimento de pastagens consorciadas em solo arenoso de cerrado. Fase I - formação (1). Boletim da Indústria Animal, v. 37, n.1, p. 173-184, 1980.

LOVADINI, L.A.C. Métodos de plantio para soja perene (Glycine wrightii Verdc.) Bragantia, v.30, n.1, p.17-19, 1971.
McWILLIAMS, J.R.; DOWLING, P.M. Factors influencing the germination and establishment of pasture seed on the soil surface. In: International Grassland Congress, 11., 1970, Brisbane.

Proceedings. Brisbane: University Queensland Press, 1970. p.578-583.

MORAES, P.V.D.; AGOSTINETTO, D.; PANOZZO, L.E.; TIRONI, S.P.; GALON, L.; SANTOS, L.S. Alelopatia de plantas de cobertura na superfície ou incorporadas ao solo no controle de Digitaria spp. Planta daninha [online]. 2011, v.29, n.spe, p.963-973. Available at: $<$ http://dx.doi.org/10.1590/ S0100-83582011000500002>. Accessed Oct. 11, 2013.

POEIRAS, L.M.; CARMO, F.M.S. A serapilheira de Eucalyptus grandis E. Hill influencia o desenvolvimento das plantas e a nodulação radicular em algumas leguminosas. In: CONGRESSO DE ECOLOGIA DO BRASIL, 8., 2007, Caxambu. Anais... Caxambu: 2007. 2p. Available at: < http://www.seb-ecologia.org.br/viiiceb/pdf/ 1802.pdf $>$. Accessed Oct. 11, 2013.

\section{R DEVELOPMENT CORE TEAM. R: A} language and environment for statistical computing. R Foundation for Statistical Computing: 2008, Disponível em: $<$ http:/ /www.R-project.org. > Accessed Jul. 02, 2014.

SILVA,V.T.; MEDRI, P.S.; FERRACIN,T.P.; BIANCHINI, E.; TOREZAN, J.M.D.; PIMENTA, J.A. Comparação entre parâmetros abióticos e a estrutura florestal de um fragmento de floresta e um reflorestamento abandonado de eucalipto (Eucalyptus saligna Smith) no parque ecológico da Klabin, Telêmaco Borba/PR. Semina:

Ciências Biológicas e da Saúde, v.31, n.1, p.37-51, 2010.

SMIL, V. Nitrogen and food production: proteins for human diets. Ambio, v.31, n.2, p.126-131, 2002.

THORNTHWAITE, C.W.; MATHER, J.R. The water balance. Publications in Climatology. New Jersey: Drexel Institute of Technology, 104p. 1955. 